\title{
Examining the Tectonic Wedging Hypothesis in the NW India Himalaya
}

\author{
A Alexander G Webb* and An Yin
}

Department of Earth and Space Sciences and Institute of Geophysics and Planetary Physics, University of California-Los Angeles, Los Angeles, California 90095-1567, USA

* For correspondence, email: awebb@ess.ucla.edu

A specific structural correlation of the Main Central thrust and the South Tibet detachment is observed in the central Himalaya, where the two faults stack three units. The high grade Greater Himalayan Crystalline complex (GHC) overlies the low grade Lesser Himalayan Sequence (LHS) along the Main Central thrust and underlies the low grade Tethyan Himalayan Sequence (THS) along the South Tibet detachment. Current tectonic models of the Himalaya (i.e., wedge extrusion, channel flow) envision the high grade middle unit (GHC) as a "pipe to the surface" of middle crustal rocks, with the two bounding faults active at the surface and without cut-off relationships. However, some regional syntheses of the western Himalayan geology suggest that the GHC is discontinuous there, in conflict with the "pipe to the surface" geometry. A new "tectonic wedging" hypothesis (à la Price 1986) may explain this structural geometry and have wide-reaching implications for the evolution of the Himalayan orogen (Yin 2006, Webb et al. 2007). In the tectonic wedging kinematic model, the GHC is emplaced at depth as a thrust horse bound below by the Main Central thrust, above by the South Tibet detachment, and up-dip (to the south) by the merging of these two faults.

Field observations and analytical data from the NW India Himalaya support a tectonic wedging kinematic model for the evolution of the Himalayan orogen. In NW India, the GHC pinches out laterally from east to west where the Main Central thrust places the THS directly on top of the LHS. Field mapping shows that this relationship results from up-dip merging of the top-south Main Central thrust below and the South Tibet detachment, with alternating top-south and top-north shear, above. Analytical data suggest stratigraphic correlations exist across the Main Central thrust and South Tibet detachment. $\mathrm{U}-\mathrm{Pb}$ zircon geochronology shows that $\sim 1.85 \mathrm{Ga}$ granite and granitic gneiss occur above and below the Main Central thrust. $\mathrm{U}-\mathrm{Pb}$ geochronology of detrital zircons suggests that correlative Late Proterozoic strata occur above the STD, below the MCT, and between these two faults. Consistent detrital zircon age populations suggest that the metasedimentary rocks of the MCT hanging wall southwest of the MCT-STD merger may belong to a single lithologic unit, supporting field evidence that includes these rocks in the basal THS. Thermobarometry of these same rocks yields temperatures of 450 to $560{ }^{\circ} \mathrm{C}$ with pressures of 7 to $9 \mathrm{kbar}$, and $\mathrm{Th}-\mathrm{Pb}$ monazite geochronology shows that this metamorphism occurred in two similar phases, one in the Paleozoic and the other in the early/middle Cenozoic. These P-T-t results are consistent with similar work on THS rocks to the north, i.e., from the STD hanging wall. The metamorphic evolution of basal THS rocks is broadly correlative to that of the GHC prior to the Late Oligocene / Early Miocene, providing another link between these sequences.

These results are synthesized into a new model of the pre-India-Asia collision stratigraphic framework of this region and a tectonic wedging kinematic model for the evolution of the Himalayan orogen. The tectonic wedging model has broad implications for exhumation and foreland sedimentation history across the entire Himalayan orogen. Since basal THS rocks and GHC rocks represent correlative strata which have experienced similar metamorphism, detritus from these units may only be distinguished by the few high grade minerals that occur exclusively in the GHC. Also, because the proposed kinematic evolution matches that of thrust systems developed in the upper 5-10 km of the crust (Price 1986), a large strength contrast between the middle crust (GHC) and upper crust (LHS, THS) is not required.

References

Price RA. 1986. The southeastern Canadian Cordillera: thrust faulting, tectonic wedging, and delamination of the lithosphere. Journal of Structural Geology 8: 239-254

Webb AAG, A Yin, TM Harrison, J Célérier and WP Burgess. 2007. The leading edge of the Greater Himalayan Crystallines revealed in the NW Indian Himalaya: Implications for the evolution of the Himalayan Orogen. Geology 35 (10):955-958

Yin A. 2006. Cenozoic tectonic evolution of the Himalayan orogen as constrained by along-strike variation of structural geometry, exhumation history, and foreland sedimentation: Earth Science Reviews 76: 1-131 